\title{
Amadeus
}

International Multidisciplinary Journal IISSN 2525-3281

DOI: 10.14295/aimj.v4i7.88

\section{Humanized Embracement in Public Health Services in Brazil}

Paula Janaynne de Souza ${ }^{l}$; Wantuil Matias Neto ${ }^{2}$; Modesto Leite Rolim Neto ${ }^{3}$

\begin{abstract}
User embracement humanization aims to enable interdisciplinary care considering the patient's reality. This literature review compiles the perspectives on humanized embracement in the Brazilian Unified Health System. We performed a BVS platform search on the keywords "attendance", "humanization" and "primary health care", filtering the results using the PRISMA protocol. It was obtained 8 articles regarding humanization in public health system care, highlighting its conditions and difficulties. It was concluded that humanized care practice is important as an improvement tool in the health system and that professionals need to adapt to the humanized model.
\end{abstract}

Keywords: User embracement; Humanization; Primary Health Care

\section{Acolhimento humanizado nos serviços públicos de saúde no Brasil}

Resumo: A humanização do acolhimento do usuário visa possibilitar um atendimento interdisciplinar considerando a realidade do paciente. Esta revisão de literatura compila as perspectivas sobre o acolhimento humanizado no Sistema Único de Saúde. Foi realizada uma busca na plataforma BVS nas palavras-chave "atendimento", "humanização" e "atenção primária à saúde", filtrando os resultados utilizando o protocolo PRISMA. Foram obtidos 8 artigos sobre humanização no sistema público de saúde, destacando suas condições e dificuldades. Concluiu-se que a prática do cuidado humanizado é importante como ferramenta de melhoria no sistema de saúde e que os profissionais precisam se adaptar ao modelo humanizado.

Palavras-Chave: Acolhimento do usuário; Humanização; Atenção Primária à Saúde

\footnotetext{
${ }^{1}$ Specialization course, Research and Innovation in Family Health, blended modality, Open University of Brazilian National Health System (UNA-SUS) - Nucleus of Ceará State, Nucleus of technology in Distance Education in Health, Federal University of Ceará. pjanaynne@gmail.com;

${ }^{2}$ Medical Residency in General Surgery of Faculty of Medicine, Federal University of Cariri - UFCA;

${ }^{3}$ Faculty of Medicine, Federal University of Cariri - UFCA. modestorolim@ yahoo.com.br.
} 


\section{Introduction}

Humanization is a relevant topic for public health, either in philosophical terms or relative to practical aspects of healthcare. In a direct sense, humanize implies in reduce the flaws in health, which involves in some aspects, understanding the meaning of health related to the subjective well-being and welfare. Therefore, the Ministry of Health developed the National Humanization Policy (NHP) in alignment with the general principles of the Unified Health System (UHS). Hence, the own State Government recognizes that in order to promote advances in the UHS, in accordance with its regulations, it is mandatory to put this policy in development (Gondim et al., 2014).

Regarding the Primary Health Care (PHC), its most important milestone was the Family Health Program (FHP) establishment that, upon its potentialities, was acknowledged as a Family Health Strategy (FHS). The FHS is based upon core principles to develop practices in health, such as person and family centering, the user connection, the attention integrality and coordination, the health care network, the social participation, and intersectoral operation. Such practices are based on NHP (Arantes et al., 2015).

At the arrival moment in the health service, the individual might be in vulnerability state and the way it is received influences the kind of relationship that will be established with the team. However, in an attempt to assist a very often large number of people that look for healthcare, the professionals might end up mechanizing the listening and the treatment, unconsciously in an automated conduction process that pulls away from the embracement logic defended by the NHP (Sato et al., 2015).

Furthermore, the architecture, the completion, the dimensions, and the service units' living rooms are some important items concerning the physical element, especially influential on the human environment preparation. Whereas, most health units are improvised physical spaces, in an inappropriate and terrible maintenance state, negatively affecting the users' reception, as well as, interfering on quality service, preventing or even restricting the privacy during the procedures (Simões et al., 2007).

Recognizing the limitations of performing over the embracing quantitative aspects considering the involved difficulties on decreasing the demand and/or increasing the staff board - it is important to develop strategies able to promote qualitative changes in the established strategies (Sato et al., 2015). 
Thereby, this work aims to perform a literature review study about the influence of humanization in the Family Health Strategy.

\section{Method}

Articles published between 2014 and 2018, indexed in the Health Virtual Library (HVL) database, were selected to this review work. The search strategy used was based on the keywords: "embracement", "humanization" and "primary health care"; also including the following limits: articles in Portuguese, English, and Spanish, available in full. The review articles were excluded, likewise the literature reviews, editorials, reviews, communications and letters to the editor. The period of search for the articles occurred between March 2, 2019, and March 20, 2019.

The selection of the articles was made by two independent evaluators and, in case of disagreement, a third examiner was summoned to reach a final consensus. Each article was read in its full content and its information was disposed in a chart, including the year of publication, authors, database, and journal. Then, the papers were submitted to three relevance tests constituted by objective questions that evaluated and quantified the relations between the search criteria and the papers founded, analyzing the connection between the article and the aims proposed by the research according to the protocol described by Muñoz et al., (2002), presented in Chart 1 .

Chart 1. Tests of relevance in Muñoz et al. (2002)

\begin{tabular}{|l|l|l|}
\hline \multicolumn{1}{|c|}{ Test I } & \multicolumn{1}{|c|}{ Test II } & Test III \\
\hline $\begin{array}{l}\text { Is the study according to the } \\
\text { subject-matter investigated? }\end{array}$ & Is the research problem clear? & Type of research \\
\hline $\begin{array}{l}\text { Was the study published in the } \\
\text { period stipulated in the project? }\end{array}$ & $\begin{array}{l}\text { Are the aims related to the matter that } \\
\text { is being studied? }\end{array}$ & Study sample \\
\hline $\begin{array}{l}\text { Was the study published in the } \\
\text { language stipulated in the project? }\end{array}$ & $\begin{array}{l}\text { Is the methodology described with } \\
\text { clarity and covers all of the objectives? }\end{array}$ & Methodology adopted \\
\hline $\begin{array}{l}\text { Does the study approach the } \\
\text { solution to the problem that is } \\
\text { being investigated? }\end{array}$ & $\begin{array}{l}\text { Are the results compatibles with the } \\
\text { methodology adopted? }\end{array}$ & Results \\
\hline \begin{tabular}{l} 
Was the study included? \\
\hline
\end{tabular}
\end{tabular}

Source: Muñoz et al., 2002 
In the final relevance test, were gathered detailed information of each article selected, allocating them into a chart to posterior analysis. The results of the research strategy were presented in Figure 1, through the PRISMA search diagram in Moher et al.,(2009). Therefore, the articles were grouped according to their main theme, enabling synthesis and discussion (Chart 2).

Chart 2. Information related to the articles selected

\begin{tabular}{|c|c|c|c|c|c|}
\hline $\begin{array}{c}\text { Author And } \\
\text { Year } \\
\end{array}$ & Journal & Aim & Methodology & Results & Conclusion \\
\hline $\begin{array}{c}\text { Arantes, et al. } \\
2016 .\end{array}$ & $\begin{array}{l}\text { Ciência } \\
\& \text { Saúde } \\
\text { Coletiva }\end{array}$ & $\begin{array}{l}\text { To identify } \\
\text { and analyze } \\
\text { the main } \\
\text { contributions } \\
\text { and challenges } \\
\text { of FHS to the } \\
\text { development } \\
\text { of Brazilian } \\
\text { PHC, with the } \\
\text { purpose to } \\
\text { discuss the } \\
\text { aspects that } \\
\text { can affect the } \\
\text { sustainability } \\
\text { of this model. }\end{array}$ & $\begin{array}{l}\text { Literary review, with } \\
\text { research for } \\
\text { publications on } \\
\text { Bireme's website } \\
\text { (www.bireme.br) in the } \\
\text { period from } 2002 \text { to } \\
\text { 2011, including } \\
\text { databases such as } \\
\text { Lilacs, IBECS, } \\
\text { Medline, Cochrane } \\
\text { Library and SciELO. } \\
\text { For descriptors, the } \\
\text { following terms were } \\
\text { used: "Primary Health } \\
\text { Care", "Family Health } \\
\text { Strategy", and as a } \\
\text { filter, paper type } \\
\text { publications, whose } \\
\text { main subject was } \\
\text { "Family Health } \\
\text { Strategy". }\end{array}$ & $\begin{array}{l}\text { In the political- } \\
\text { institutional } \\
\text { dimension, it was } \\
\text { verified that the FHS } \\
\text { promoted primary } \\
\text { care broadening in the } \\
\text { Country. In the } \\
\text { organizational } \\
\text { dimension, the FHS } \\
\text { implementation } \\
\text { contributed to the } \\
\text { expansion of the } \\
\text { possibilities, offering } \\
\text { services in the } \\
\text { peripheral and rural } \\
\text { areas. In the } \\
\text { technical- } \\
\text { assistance dimension, } \\
\text { the FHS was better } \\
\text { than the PHC model } \\
\text { in traditional Basic } \\
\text { Health Unity. }\end{array}$ & $\begin{array}{l}\text { It is evident that the } \\
\text { FHS has presented } \\
\text { several advances, } \\
\text { however, it faces } \\
\text { problems, mainly } \\
\text { imposed by the } \\
\text { federative structure } \\
\text { of the country and } \\
\text { the great regional } \\
\text { imbalances, in } \\
\text { addition to an } \\
\text { important growth of } \\
\text { the private sector in } \\
\text { recent times, which } \\
\text { makes difficult the } \\
\text { PHC organization as } \\
\text { the health system's } \\
\text { main axis. }\end{array}$ \\
\hline $\begin{array}{c}\text { Fertonani, et } \\
\text { al. } 2015 .\end{array}$ & $\begin{array}{l}\text { Ciência } \\
\& \text { Saúde } \\
\text { Coletiva }\end{array}$ & $\begin{array}{l}\text { To restore the } \\
\text { debate about } \\
\text { the conceptual } \\
\text { formulations } \\
\text { of care model } \\
\text { in health and } \\
\text { the challenges } \\
\text { for the primary } \\
\text { care in Brazil. }\end{array}$ & $\begin{array}{l}\text { The study characterizes } \\
\text { different concepts and } \\
\text { terminologies related to } \\
\text { the care model's } \\
\text { expression and shows } \\
\text { that family health has } \\
\text { promoted extended } \\
\text { access as well as } \\
\text { embracement and } \\
\text { humanization } \\
\text { incorporation to the } \\
\text { practices. }\end{array}$ & $\begin{array}{l}\text { There is a persistence } \\
\text { of the treatment } \\
\text { centralization in } \\
\text { pathologies and the } \\
\text { biological body's } \\
\text { care, difficulties in } \\
\text { the implementation of } \\
\text { integrality, deficits in } \\
\text { the teams, working } \\
\text { conditions and } \\
\text { relationships. }\end{array}$ & $\begin{array}{l}\text { The term "care } \\
\text { model" is polysemic } \\
\text { and although there } \\
\text { are proposals and } \\
\text { structural policies } \\
\text { for a model that } \\
\text { advances regarding } \\
\text { the biomedical } \\
\text { paradigm, there are } \\
\text { significant } \\
\text { difficulties for its } \\
\text { implementation. }\end{array}$ \\
\hline
\end{tabular}




\begin{tabular}{|c|c|c|c|c|c|}
\hline $\begin{array}{l}\text { Schveitzer, et } \\
\text { al. } 2016 .\end{array}$ & $\begin{array}{l}\text { Revista } \\
\text { Latino- } \\
\text { America } \\
\text { na de } \\
\text { Enferma } \\
\text { gem } \\
\text { (RLAE) }\end{array}$ & $\begin{array}{l}\text { To identify the } \\
\text { nursing } \\
\text { challenges for } \\
\text { universal } \\
\text { health } \\
\text { coverage, } \\
\text { based on the } \\
\text { results of a } \\
\text { systematic } \\
\text { review, } \\
\text { focusing on } \\
\text { the } \\
\text { understanding } \\
\text { of the health } \\
\text { workforce on } \\
\text { the role of } \\
\text { humanization } \\
\text { practices in } \\
\text { Primary Care. }\end{array}$ & $\begin{array}{l}\text { Systematic review and } \\
\text { meta-synthesis, starting } \\
\text { from the following } \\
\text { sources of information: } \\
\text { PubMed, CINAHL, } \\
\text { Scielo, Web of Science, } \\
\text { PsycInfo, SCOPUS, } \\
\text { DEDALUS and } \\
\text { Proquest, using the } \\
\text { keyword "Primary } \\
\text { Health Care", } \\
\text { separately associated to } \\
\text { the following } \\
\text { keywords: } \\
\text { humanization of } \\
\text { assistance, holistic } \\
\text { care/health, patient- } \\
\text { centered care, user } \\
\text { embracement, personal } \\
\text { autonomy, holism, } \\
\text { attitude of health } \\
\text { professionals. }\end{array}$ & $\begin{array}{l}\text { Work processes in } \\
\text { primary care are } \\
\text { complex and present } \\
\text { difficulties for } \\
\text { holistic care practice, } \\
\text { especially for nursing. } \\
\text { However, humanizing } \\
\text { practices have } \\
\text { demonstrated its } \\
\text { important role in a } \\
\text { positive work } \\
\text { environment } \\
\text { development, and to } \\
\text { people-centered care } \\
\text { and attention quality } \\
\text { by promoting } \\
\text { accessibility and } \\
\text { universal health } \\
\text { coverage. }\end{array}$ & $\begin{array}{l}\text { The challenges of } \\
\text { nursing for universal } \\
\text { health coverage are } \\
\text { related to education } \\
\text { and training, better } \\
\text { working conditions } \\
\text { and a clear } \\
\text { definition of the } \\
\text { nursing's role in } \\
\text { primary care. }\end{array}$ \\
\hline $\begin{array}{c}\text { Sato; Ayres. } \\
2015 .\end{array}$ & $\begin{array}{l}\text { Interface } \\
- \\
\text { Comunic } \\
\text { ação, } \\
\text { Saúde, } \\
\text { Educação }\end{array}$ & $\begin{array}{l}\text { To reflect on } \\
\text { art's potentials } \\
\text { in health } \\
\text { services' } \\
\text { humanization } \\
\text { processes. }\end{array}$ & $\begin{array}{l}\text { Reflection with } \\
\text { philosophical } \\
\text { contributions about a } \\
\text { project of humanization } \\
\text { in healthcare. Based on } \\
\text { the experience of using } \\
\text { art in a project to } \\
\text { improve the reception } \\
\text { and ambiance at a } \\
\text { Basic Health Unity in } \\
\text { the city of São Paulo. }\end{array}$ & $\begin{array}{l}\text { The phenomenon } \\
\text { investigation } \\
\text { demonstrated that the } \\
\text { art would have } \\
\text { properties capable of } \\
\text { involving the subjects } \\
\text { in an experiment that } \\
\text { could promote the } \\
\text { creation of new } \\
\text { meanings for the } \\
\text { waiting room. }\end{array}$ & $\begin{array}{l}\text { The main outcome } \\
\text { of the current } \\
\text { reflection points to } \\
\text { art's potentiality in } \\
\text { the health } \\
\text { resignification of } \\
\text { working in health } \\
\text { processes in its way } \\
\text { as humanized } \\
\text { practice. }\end{array}$ \\
\hline $\begin{array}{l}\text { Cavalcanti, et } \\
\text { al. } 2014 .\end{array}$ & $\begin{array}{l}\text { Escola } \\
\text { Anna } \\
\text { Nery } \\
\text { Revista } \\
\text { de } \\
\text { Enferma } \\
\text { gem }\end{array}$ & $\begin{array}{l}\text { To know the } \\
\text { health needs, } \\
\text { identifying the } \\
\text { obstacles that } \\
\text { restrain } \\
\text { meeting men's } \\
\text { health needs } \\
\text { and to present } \\
\text { coping } \\
\text { strategies for } \\
\text { integral and } \\
\text { humane } \\
\text { assistance to a } \\
\text { group of men. }\end{array}$ & $\begin{array}{l}\text { A descriptive and } \\
\text { exploratory study, with } \\
\text { a qualitative approach. } \\
\text { Data collection was } \\
\text { performed in February } \\
2012 \text { through a semi- } \\
\text { structured interview } \\
\text { and analyzed according } \\
\text { to a theoretical } \\
\text { framework. }\end{array}$ & $\begin{array}{l}\text { The male population } \\
\text { has health needs to be } \\
\text { met and refer to } \\
\text { obstacles as the } \\
\text { shame of exposure, } \\
\text { impatience, lack of } \\
\text { time and resolution of } \\
\text { health needs. } \\
\text { Humanization in } \\
\text { health predominated } \\
\text { as a coping strategy, } \\
\text { through access, } \\
\text { embracement, } \\
\text { communication, and } \\
\text { connection.. }\end{array}$ & $\begin{array}{l}\text { The Policy for } \\
\text { Integral Attention to } \\
\text { Men's Health was } \\
\text { not enough to insert } \\
\text { them into the health } \\
\text { context, this way, } \\
\text { changes are } \\
\text { proposed in the care } \\
\text { model. }\end{array}$ \\
\hline $\begin{array}{c}\text { Gondim; } \\
\text { Andrade. } \\
2014 .\end{array}$ & $\begin{array}{l}\text { Revista } \\
\text { Portugue } \\
\text { sa de } \\
\text { Saúde } \\
\text { Pública }\end{array}$ & $\begin{array}{l}\text { The article } \\
\text { analyzes the } \\
\text { demand for } \\
\text { humanized } \\
\text { care in } \\
\text { primary health }\end{array}$ & $\begin{array}{l}\text { A descriptive study } \\
\text { with } 345 \text { users of a } \\
\text { health service in a city } \\
\text { of northeastern Brazil. } \\
\text { The demand for } \\
\text { services and humanized }\end{array}$ & $\begin{array}{l}\text { Humanized care and } \\
\text { user satisfaction are } \\
\text { directly related to } \\
\text { embracement } \\
\text { received by } \\
\text { employees and health }\end{array}$ & $\begin{array}{l}\text { The user's } \\
\text { perspective over the } \\
\text { care quality, respect } \\
\text { and education } \\
\text { constitute necessary } \\
\text { factors to a human }\end{array}$ \\
\hline
\end{tabular}




\begin{tabular}{|c|c|c|c|c|c|}
\hline & & care. & $\begin{array}{l}\text { care (respect and } \\
\text { education, attention, } \\
\text { interest, fast service } \\
\text { and information } \\
\text { transfer) were studied. }\end{array}$ & professionals. & $\begin{array}{l}\text { and sensitive } \\
\text { doctor/patient } \\
\text { relationship. }\end{array}$ \\
\hline Cruz. 2017 & $\begin{array}{l}\text { Bibliotec } \\
\text { a digital } \\
\text { da USP }\end{array}$ & $\begin{array}{l}\text { To identify } \\
\text { issues related } \\
\text { to work and } \\
\text { the production } \\
\text { of health care } \\
\text { that interfere } \\
\text { on specialized } \\
\text { assistance's } \\
\text { embracement } \\
\text { and the } \\
\text { humanization; } \\
\text { to interpret the } \\
\text { relation } \\
\text { between the } \\
\text { different } \\
\text { professional } \\
\text { practices; to } \\
\text { understand } \\
\text { workers and } \\
\text { users' } \\
\text { perceptions } \\
\text { about the } \\
\text { humanization } \\
\text { in health and } \\
\text { the } \\
\text { embracement } \\
\text { as a guideline } \\
\text { for the NHP. }\end{array}$ & $\begin{array}{l}\text { A qualitative study, } \\
\text { conducted in the clinic } \\
\text { of medical specialties } \\
\text { of the Hospital das } \\
\text { Clinicas do Acre } \\
\text { (HCAC), between } \\
\text { September } 2015 \text { and } \\
\text { January } 2016 \text {. Four } \\
\text { focus groups (user, } \\
\text { support workers, } \\
\text { physicians, and other } \\
\text { health professionals) } \\
\text { were carried out and } \\
\text { three semi-structured } \\
\text { interviews (service } \\
\text { management and } \\
\text { ombudsman). Based on } \\
\text { the host directive, the } \\
\text { NHP, and the } \\
\text { micropolitics, the } \\
\text { message's theme } \\
\text { content analysis grant } \\
\text { building four thematic } \\
\text { categories. }\end{array}$ & $\begin{array}{l}\text { Primary Health Care } \\
\text { (PHC), the regulatory } \\
\text { complex and medical } \\
\text { care in PHC, } \\
\text { represent sensitive } \\
\text { points in the Health } \\
\text { Care Network } \\
\text { (HCN).In specialized } \\
\text { care, the bureaucratic } \\
\text { management model } \\
\text { and ambiance related } \\
\text { factors hinder } \\
\text { embracement's } \\
\text { deployment. The } \\
\text { humanization and } \\
\text { embracement for } \\
\text { users reflect on } \\
\text { respect, education and } \\
\text { good service } \\
\text { performed by the } \\
\text { worker. }\end{array}$ & $\begin{array}{l}\text { The embracement } \\
\text { directive has been } \\
\text { shown as a possible } \\
\text { humanization } \\
\text { strategy to be } \\
\text { implemented in the } \\
\text { specialized service, } \\
\text { despite all the } \\
\text { problems and } \\
\text { challenges related to } \\
\text { the ambulatory in } \\
\text { HCAC and the } \\
\text { HCN. This way, the } \\
\text { management should } \\
\text { consider the } \\
\text { introduction of } \\
\text { technological } \\
\text { devices for } \\
\text { embracement and } \\
\text { collective spaces for } \\
\text { listening to the } \\
\text { worker. }\end{array}$ \\
\hline Zanotto. 2016. & $\begin{array}{l}\text { The } \\
\text { Federal } \\
\text { Universit } \\
\text { y of } \\
\text { Santa } \\
\text { Catarina, } \\
\text { course of } \\
\text { physiothe } \\
\text { rapy }\end{array}$ & $\begin{array}{l}\text { To analyze the } \\
\text { perception of } \\
\text { users and } \\
\text { professionals } \\
\text { of the Family } \\
\text { Health Team } \\
\text { (FHT) about } \\
\text { the quality of } \\
\text { Primary Care } \\
\text { assistance with } \\
\text { the experience } \\
\text { of } \\
\text { implementing } \\
\text { the "Mais } \\
\text { Médicos" } \\
\text { (More } \\
\text { Doctors) } \\
\text { Program. }\end{array}$ & $\begin{array}{l}\text { Semi-structured } \\
\text { interviews with } \\
\text { professionals, users, } \\
\text { and a survey with } \\
\text { questions taken from } \\
\text { the National Program } \\
\text { for Access and Quality } \\
\text { Improvement in } \\
\text { Primary Care (PMAQ). } \\
\text { The interviews were } \\
\text { transcribed and } \\
\text { analyzed through } \\
\text { thematic analysis and } \\
\text { the survey's } \\
\text { information was } \\
\text { analyzed by absolute } \\
\text { frequency, discussed in } \\
\text { a qualitatively, through } \\
\text { Minayo's Thematic } \\
\text { Analysis. }\end{array}$ & $\begin{array}{l}\text { It was observed that } \\
\text { the care provided by } \\
\text { the doctor linked to } \\
\text { the Program was } \\
\text { more humanized and } \\
\text { integral. While by } \\
\text { professionals of the } \\
\text { Health Team } \\
\text { perception, there } \\
\text { were no differences } \\
\text { related to the team's } \\
\text { dynamic, this was } \\
\text { mainly due to excess } \\
\text { on work demand that } \\
\text { hinders the team's } \\
\text { organization. }\end{array}$ & $\begin{array}{l}\text { The work done by } \\
\text { the More Doctors } \\
\text { Program is more } \\
\text { humanized and } \\
\text { better evaluated by } \\
\text { the health system } \\
\text { users.. }\end{array}$ \\
\hline
\end{tabular}

Source: Research Data. 


\section{Results}

Figure 1. Diagram with the results of the search strategies
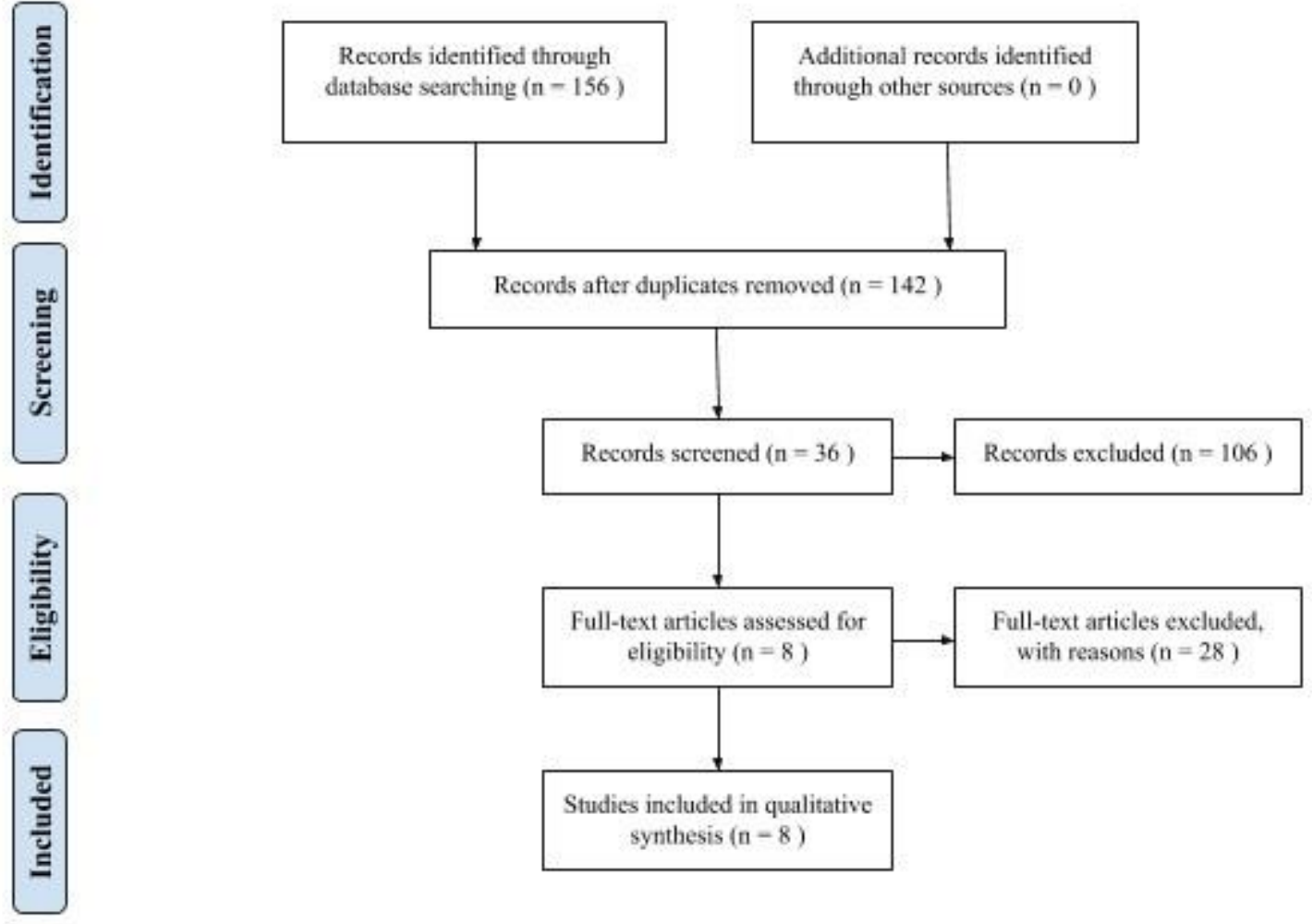

Source: Schematic representation of the studies included in the systematic review using a checklist and flow diagram of the PRISMA Protocol.

\section{Discussion}

Humanization in health is described as the mean by which the UHS - Unified Health System embraces and guarantees the public health services users. In this respect, while the UHS is the entry point for the health service needs, as foreseen in this system's guidelines and principles, the humanized embracing has its main difficulties as ethicaloriented, evolving the attitudes among users, health professionals and conscious managers, besides evolving the production of autonomous health and subjectivity, regarding the way in which each individual acts and understands the environment actions. 
In the health field, the concept of humanizing arises as a principle tied to the human rights paradigm - expressed individual and socially - and referred to patients, users, consumers, clients and citizens as subjects. At the end of the 1990s, the concept of humanization was established as the core principle of two health programs in the Brazilian public sector, the Prenatal and Birth Humanization Program (PBHP) and the Hospital Care Humanization program (HCHP), culminating in the National Humanization Policy (NHP) (Vaitmsan; Andrade, 2005).

The implementation of health services that consider the patient's sociocultural perspectives is the vision NHP has about the policy's execution of UHS. The UHS was set in 2003 with services guidelines such embracement, co-management, ambiance, enlarged clinic, worker appreciation, and user-rights defense, guided by the transversality, inextricable connection between attention, management, and protagonism, as well as, coresponsibility and autonomy of subjects and collectives (Brasil, 2004, 2013).

To that end, the humanization policy is presented as an important milestone for the construction of health practices that effectively respect the citizens' values and needs (Pasche; Passos; Hennington, 2011).

Nevertheless, it is necessary to take into consideration the society's organization, the institutionality of care practices and public health management that shape public action policies. In this respect, it is possible to analyze, in advance, the health professionals' reality, from professional education to updates humanized embracementoriented, based on the humanization policy which is based on changes in the way of managing and caring with the transversality, autonomy, and protagonism of the subjects. Since, according to Romano (2007), medical students having no parameters or models to follow, end up reproducing the medical culture they were exposed, from practice with a focus solely on the disease, insecurity while handling psychological, social and environmental issues, with limited health promotion and prevention action.

Within this context, it is possible to infer the relationship between the entry points of the health public system with medical conduct and its challenges. The FHS - Family Health Strategy is the main entry point to UHS and, at the same time, the main way for establishing a bond, embracement, and family emphasis noticed that especially by the proximity with the community, by example the domiciliary visits. However, it still stands out the individualization and specification of disease focus as a paradigm. For Ogata, Machado e Catóia (2009), the focus on the disease in the medical conduct, as it is still seen 
in some work realities, fragilize the creation of interpersonal ties and, for this reason, it can affect the adherence to treatment, participation in educational practices and actions aimed at promoting the quality of user's life.

For Coelho, Antunes e Oliveira (2019), the practice of health and family medicine, has its effectiveness in the community and must take into account the context in which it is being developed and the daily challenges to its exercise, considering yet Brazil's continental dimensions, and its socio-cultural pluralities. Given that, the UHS coordinates its actions based on principles and values among which is included the humanization as a way to produce changes in the way of managing and caring.

Thus, the communication stimulus between managers, workers, and users of public health care, intensify actions aimed at preventing dehumanized practices, as well as, the acknowledging of the communities' wishes. In order to do so, the Ministry of Health created the NHP to disseminate innovations in the way of doing health care, in view of reaching the individual in full as well, reaching the longitudinal age by strengthening ties in the main entry points of the UHS. Knowing that, and according to the National Humanization Policy (2013), it is possible to assure humanization importance in the health-sickness process.

\section{Conclusion}

Therefore, the humanized health practice in FHS is an important factor in the health-disease process of the population, since the implantation of the FHS produced several favorable results to the population's health (Arantes; Shimizu; Merchán-Hamann, 2016).

However, users' opinion about humanization politics, according to Oliveira, 2017, is still negative, indicating problems such as the lack of professional preparation. In this sense, the main challenge in the adoption of the humanized model is the break of the biomedical model, which prevents the recognition of other "truths" about the health care, opposed to the reductionism of clinical pathology and mechanical physiology (Schveitzer; Zoboli; Vieira, 2016). 
Thus, the articles evaluated in this literary review point the interrelation between the health practice and the humanization of caring, which allows to conclude that the humanizing practices are a benefit whose practice must be expanded.

\section{References}

Arantes, Luciano José; Shimizu, Helena Eri; Merchán-Hamann, Edgar (2016). Contribuições e desafios da Estratégia Saúde da Família na Atenção Primária à Saúde no Brasil: revisão da literatura. Ciência \& Saúde Coletiva, [s.1.], v. 21, n. 5, p. 1499-1510, May. FapUNIFESP (SciELO). Available on: <http://dx.doi.org/10.1590/1413-81232015215.19602015>.

Brasil, Ministério da Saúde (2013). Política Nacional de Humanização. Brasília: Ed. Premium. Available on:

<http://bvsms.saude.gov.br/bvs/publicacoes/politica_nacional_humanizacao_pnh_folheto.pd>. Access on: Apr. 10, 2019.

Brasil, Ministério da Saúde (2004). Política Nacional de Humanização: Documento base para Gestores e Trabalhadores do SUS. Brasília: MS.

Cavalcanti, Joseane da Rocha Dantas et al. (2014). Assistência Integral a Saúde do Homem: necessidades, obstáculos e estratégias de enfrentamento. Esc. Anna Nery, Rio de Janeiro, v. 18, n. 4, p. 628-634, Dec. Available on: <http://www.scielo.br/scielo.php?script =sci_arttext\&pid=S1414-81452014000400628\&lng=en\&nrm=iso>. Access on: Apr. 13, 2019. http://dx.doi.org/10.5935/1414-8145.20140089.

Coelho, Giliate Cardoso, Antunes, Valeska Holst e Oliveira, Aristides (2019). A prática da Medicina de Família e Comunidade no Brasil: contexto e perspectivas. Cadernos de Saúde Pública [online]. v. 35, n. 1 [Access: Apr. 12, 2019], e00170917. Available on: <https://doi.org/10.1590/0102-311X00170917>. Epub 10 Jan 2019. ISSN 1678-4464. https://doi.org/10.1590/0102-311X00170917.

Cruz, Jene Greyce Oliveira da (2017). O acolhimento na assistência especializada no estado do Acre: micropolítica e produção do cuidado em saúde. Tese (Doutorado em Serviços de Saúde Pública) - Faculdade de Saúde Pública, Universidade de São Paulo, São Paulo, 2017. doi:10.11606/T.6.2017.tde-27062017-110416. Access on: Apr. 13, 2019.

Fertonani, Hosanna Pattrig et al. (2015). Modelo assistencial em saúde: conceitos e desafios para a atenção básica brasileira. Ciência \& Saúde Coletiva, [s.1.], v. 20, n. 6, p. 1869-1878, Jun. FapUNIFESP (SciELO). http://dx.doi.org/10.1590/1413-81232015206.13272014.

Gondim, Ana Paula Soares; Andrade, João Tadeu de (2014). Cuidado humanizado na atenção primária à saúde: demanda por serviços e atuação profissional na rede de atenção primária à saúde - Fortaleza, Ceará, Brasil. Revista Portuguesa de Saúde Pública, [s.1.], v. 32, n. 1, p. 6168, Jan. Elsevier BV. http://dx.doi.org/10.1016/j.rpsp.2014.01.002.

Moher et al. (2009). The PRISMA Group. Preferred Reporting Items for Systematic Reviews and Meta-Analyses: The PRISMA Statement. PLoS Med 6(6): e1000097. doi:10.1371/journal.pmed1000097. 
Muñoz S. I. S. et al. (2002). Revisão sistemática de literatura e metanálise: noções básicas sobre seu desenho, interpretação e aplicação na área da saúde. In: Anais do $8^{\circ}$ Simpósio Brasileiro de Comunicação em Enfermagem. Nov. 06; São Paulo, Brasil [CD- ROM]. São Paulo: Universidade de São Paulo; 2002.

Pasche, Dário Frederico; Passos, Eduardo; Hennington, Élida Azevedo (2011). Cinco anos da política nacional de humanização: trajetória de uma política pública. Ciênc. saúde coletiva, Rio de Janeiro, v. 16, n. 11, p. 4541-4548, Nov. Available from <http://www.scielo.br/scielo.php?script=sci_arttext\&pid=S141381232011001200027\&lng=en \&nrm=iso>. Access on: Apr. 12, 2019. $\quad$ http://dx.doi.org/10.1590/S1413 812320110012 00027.

Romano, V. F. (2007). A busca de uma identidade para o médico da família. Rio de Janeiro: Physis: Revista de saúde coletiva.

Sato, Mariana; Ayres, José Ricardo de Carvalho Mesquita (2015). Arte e humanização das práticas de saúde em uma Unidade Básica. Interface - Comunicação, Saúde, Educação, [s.1.], v. 19, n. 55, p. 1027-1038, Dec. FapUNIFESP (SciELO). http://dx.doi.org/10.1590/180757622014.0408 .

Schveitzer, Mariana Cabral; Zoboli, Elma Lourdes Campos Pavone; Vieira, Margarida Maria da Silva (2016). Nursing challenges for universal health coverage: a systematic review. Rev. Latino-Am. Enfermagem, v. 24, and 2676. Available on: $<$ http://www.revenf.bvs.br/scielo.php?script=sci_arttext\&pid=S010411692016000100600\&lng $=$ pt\&nrm=iso $>$. Access on Apr. 13, 2019. Epub Apr. 29, 2016. http://dx.doi.org/10.1590/1518-8345.0933.2676.

Simões, Ana Lúcia de Assis et al. (2007). Humanização na Saúde: Enfoque na Atenção Primária. Florianópolis, v. 3, n. 16, p. 439-444, Jun, 11. Monthly

Vaitsman, Jeni; Andrade, Gabriela Rieveras Borges de (2005). Satisfação e responsividade: formas de medir a qualidade e a humanização da assistência à saúde. Ciências \& Saúde Coletiva, Rio de Janeiro, v. 10, n. 3, p. 599-613, Apr.

Zanotto, Wanessa (2016). Programa Mais Médicos: A Percepção dos usuários e profissionais da equipe de Saúde da Família a respeito da Qualidade da Assistência no Extremo Sul Catarinense. 119 f. TCC (Graduação) - Curso de Fisioterapia, Universidade Federal de Santa Catarina, Santa Catarina, 2016.

\section{How to cite this article (APA format):}

Souza, Paula Janaynne de; Matias Neto, Wantuil; Rolim Neto, Modesto Leite (2019). Humanized Embracement in Public Health Services in Brazil. Am. In. Mult. J., October. (7) $4,178-188$.

Received: $11 / 25 / 2019$

Accepted: 12/04/2019 